\title{
The intention to use mobile banking: Further evidence from Saudi Arabia
}

\author{
I.M. Al-Jabri \\ Department of Accounting \& MIS, College of Industrial Management, King Fahd University of Petroleum \& Minerals, \\ Dhahran 31261, Saudi Arabia \\ *To whom all correspondence should be addressed \\ imjabri@kfupm.edu.sa
}

\begin{abstract}
The purpose of this research paper is to develop and examine a research model to understand the factors that affect the intention to use mobile banking services in Saudi Arabia. Based on a paper-based survey of 253 respondents, the study utilized a Partial Least Squares (PLS) to empirically test the model. The results indicated strong support for the validity of proposed model with $66,7 \%$ of the variance in intention to use mobile banking. The results also indicated that compatibility was the strongest facilitator of intention while perceived risk was a barrier to the intention to use mobile banking. Trust had strong negative relationship with perceived risk, indicating that trust may alleviate the risk barrier, which could influence intention to use mobile banking. Contrary to previous research, perceived usefulness and perceived ease of use did not have significant effect on intention to use mobile banking. The implications of the findings were discussed and suggestions for future research were presented.
\end{abstract}

\section{Introduction}

Banks in Saudi Arabia operate in a very competitive environment. Competition for customer deposits and investments is intense and banks strive to provide state-ofthe-art services for their customers, especially at the retail or personal level. Driven by the increasing penetration rate of mobile subscriptions in Saudi Arabia which reached 181\% in the third quarter of 2012 (Ethos Interactive, 2012) while $60 \%$ of the Saudi population own smart phones (CITC, 2012), Saudi banks have started to provide e-banking solutions for their clients through the usage of the land-line phones (Al-Ashban \& Burney, 2001), internet (Al-Somali, Gholami \& Clegg, 2009) and mobile phones (Al-Jabri \& Sohail, 2012). Until recently, most customers have lined up in queues in banks' branches or at best use the Automatic Teller Machines (ATMs) to conduct their banking transactions. However, the introduction of the Internet in 1999 and its widespread use amongst residents of Saudi Arabia thereafter had allowed banks to utilize technology to build IT infrastructures that enabled them to provide on-line banking transactions for their customers. Currently, there are twelve Saudi banks operating in Saudi Arabia. Only five of them provide mobile banking services. The twelve Saudi banks are competing to facilitate banking transactions for their customers; however, the level of services provided differs among these banks. Some deployed state-of-the-art IT infrastructure and systems for conducting banking transactions while others still lag behind in terms of platform, system reliability, and the number of services.

The development of mobile applications has led some Saudi banks to introduce software applications on mobile phones to enable their clients to conduct banking transactions on their mobile devices without the need to use ATMs, land- line phones, queuing up in branches, or even using the normal internet on their laptops. The specific benefit of this added service is banking from anywhere at anytime without having to be located in any specific place. With the rapid advancements in mobile technology associated with its decreasing costs, many customers in Saudi Arabia would find it handy and convenient to use mobile banking services to conduct their financial transactions. Hence, the mobile banking in Saudi Arabia is on the rise as banks introduce more mobile banking services. However, there is lack of knowledge on how customers perceive these mobile banking services. This gap of knowledge motivated this research initiative. Therefore, this paper is an attempt to increase our understanding of the factors that bank customers perceive as important to their intention to use mobile banking in Saudi Arabia.

The rest of the paper is organized as follows. The next section briefly presents the state of electronic banking in Saudi Arabia, followed by literature review, research model hypotheses, research methodology, results, discussion, conclusion and implications, and finally the limitation and for future research.

\section{Electronic banking in Saudi Arabia}

In 2000 , few Saudi financial institutions have started providing banking transactions on the Internet. The growth of the internet coupled with the effects of globalization and the growing need for banks to provide banking services for their clients has led some of these banks to stay ahead of the curye and introduce internet banking and mobile banking for their individual and commercial clients. The complex operating environment and the competitive global environment in which Saudi banks operate necessitate 
introducing new service channels from which to retain existing clients and acquire new ones.

The proliferation of internet lines and smart phones paved the way for banks to think of additional offering channels. Saudi Arabian Monetary Agency (SAMA), acting as the central bank, regulates, encourages, and sometimes forces Saudi banks to embrace information technology in their business operations, especially payments and fund transfers. In October, 2004, SAMA launched a payment system known as Sadad. The core mandate of Sadad is to facilitate and streamline bill payment transactions of end consumers through all channels of the Kingdom's Banks. Currently, bank's individual and business customers pay bills through Sadad using all the available banking channels. These channels are bank's branches, ATMs, internet banking, phone banking, and mobile banking. Table 1 presents the volume of bills paid through Sadad and other channels. It is evident that transactions through e-channels are on the rise and those on conventional channels are declining. The volume of bills paid through e-channels has increased from $43 \%$ to $90 \%$ from 2007 to 2011 , respectively; while the bills paid through traditional channels have decreased from $57 \%$ to $10 \%$.

Table 1: Volume of bills paid through electronic and other channels

\begin{tabular}{rrrrrr}
\hline Year & $\begin{array}{r}\text { No, of bills paid thru } \\
\text { e.channels }\end{array}$ & $\%$ & $\begin{array}{r}\text { No. of bills paid thru other } \\
\text { channels }\end{array}$ & $\%$ Total \\
\hline 2007 & $18,879,056$ & 43 & $24,634,341$ & 57 & $43,513,397$ \\
2008 & $64,324,990$ & 88 & $8,899,521$ & 12 & $73,224,511$ \\
2009 & $67,703,935$ & 89 & $8,709,887$ & 11 & $76,413,822$ \\
2010 & $98,888,957$ & 91 & $9,896,584$ & 9 & $108,785,541$ \\
2011 & $123,696,182$ & 90 & $13,886,831$ & 10 & $137,583,013$ \\
\hline
\end{tabular}

Source: Monthly Statistical Bulletin (Jan. 2012)

Currently, there are twelve Saudi banks operating in Saudi Arabia. As shown in Table 2, only five banks provide mobile banking services. These services include balance inquiry of latest transactions, fund transfer between accounts in the same bank and otherwise, mutual fund subscription and redemption, utility bill payments, check book ordering, and customer feedback. All these services are for individual and not for commercial clients, however, some banks provide on-line services for their commercial clients and supplement platforms for conducting business and commercial transactions. The common theme is that almost all available services for individuals that can be performed on mobile phones can also be performed face-to-face in the branch, ATM, and online. The trend of mobile banking service provision is increasing but awareness of the service by banking customers and the convenience that it entails requires more effort on the part of banking services providers. Some banks respond to market needs, demographic, economic, and technological changes; others follow suit simply because they are imitators.

Table 2: Saudi banks that provide mobile banking and other electronic channels

\begin{tabular}{|c|c|c|c|c|c|}
\hline SN & Bank & Online Banking & M-Banking & ATM & Telephone \\
\hline 1 & AlRajhi Bank & $\sqrt{ }$ & $\sqrt{ }$ & $\sqrt{1}$ & $\sqrt{1}$ \\
\hline 2 & Saudi Fransi Bank & $\sqrt{ }$ & $\sqrt{ }$ & $\sqrt{ }$ & $\sqrt{ }$ \\
\hline 3 & AlBilad Bank & $\sqrt{ }$ & $\sqrt{ }$ & $\sqrt{ }$ & $d$ \\
\hline 4 & AlJazirah Bank & $\sqrt{ }$ & $\sqrt{ }$ & $\sqrt{ }$ & $\sqrt{ }$ \\
\hline 5 & SAMBA Financial Group & $\sqrt{ }$ & $\sqrt{ }$ & $\sqrt{ }$ & $\sqrt{ }$ \\
\hline 6 & Riyad Bank & $\sqrt{ }$ & $\mathrm{X}$ & $\sqrt{ }$ & $\sqrt{1}$ \\
\hline 7 & AlInma Bank & $\sqrt{ }$ & $\mathrm{X}$ & $\sqrt{ }$ & $\sqrt{ }$ \\
\hline 8 & AlAhli Bank (NCB) & $\sqrt{ }$ & $\mathrm{X}$ & $\sqrt{ }$ & $\sqrt{ }$ \\
\hline 9 & $\mathrm{SABB}$ & $\sqrt{ }$ & $\mathrm{X}$ & $\sqrt{ }$ & $\mathrm{x}$ \\
\hline 10 & Saudi Hollandi Bank & $\mathrm{X}$ & $\mathrm{X}$ & $\sqrt{ }$ & $\sqrt{ }$ \\
\hline 11 & Saudi Investment Bank & $\gamma$ & $\mathrm{X}$ & $\sqrt{ }$ & $\sqrt{ }$ \\
\hline 12 & Arab National Bank & $\sqrt{ }$ & $\mathrm{X}$ & $\checkmark$ & $\mathrm{X}$ \\
\hline
\end{tabular}

\section{Literature review}

Advancements in technology have led many individuals to use technology as a tool to communicate, get information and news, and buy products and services online. Like the internet, mobiles phones also could be used to purchase goods and services from anywhere and at anytime. One of the new areas of service in the mobile technology is mobile banking. It represents a challenge for financial services providers to launch their own mobile banking applications to retain their current customers and tap into this technology-driven service channel to acquire new technology savry customers. There are factors that would enable banks to use this technology to influence their customers to conduct banking transactions on mobile devices. The theoretical foundation of this study is based on 
the Technology Acceptance Model (TAM) and Innovation Diffusion Theory (IDT).

\section{Technology acceptance model}

Davis (1986) proposed TAM in adaptation of the Theory of Reasoned Action (TRA) (Fishbein \& Ajzen, 1975). TAM is a theoretical model for explaining users acceptance of information technology. According to the TRA, actual behavior of an individual is determined by his/her intention. Moreover, an individual's behavioral intention is influenced by his/her attitude and subject norm. The attitude is influenced by individual's beliefs and value system (Ajzen \& Fishbein, 1980). Revised TAM identified perceived usefulness and perceived ease of use as core salient beliefs explaining users' intention to acceptance of information technology (Davis, Bagozzi \& Warshaw, 1989). Perceived usefulness is defined as "the degree to which a person believes that using a particular system would enhance his or her job performance" (Davis 1989; 320). Ease of use is defined as "the degree to which a person believes that using a particular system would be free of effort" (Davis 1989: 320). Moreover, perceived ease of use positively affect perceived usefulness because the easier IT is to be used, the more useful it will be. TAM is a well-tested model for measuring users' acceptance of IT (Lee, Lee \& Kim, 2007; Lin, Fofanah \& Liang, 2011; Park, Roman, Lee \& Chung, 2009; Riffai, Grant \& Edgarc, 2012; Suh \& Han, 2002; Sundarraj \& Manochehri, 2011).

Beside the two determinants of TAM, trust is a key construct in e-commerce (Bhattacherjee, 2002; Pavlou, 2003) e-banking (Zhao \& Koenig-Lewis, 2010; Mahdi, 2012), and mobile banking (Kim, Shin \& Lee, 2009; Zhou, $2011,2012)$ because transactions are conducted without interactions with bank's clerks (Gefen, Karahanna \& Straub, 2003). Trust is defined as an individual belief that others will behave based on an individual's expectation. It is related to an individual's perceived security of the transactions conducted on the internet or on mobile devices. Some research have been conducted on internet banking, ecommerce and m-commerce, online shopping, the WorldWide Web, micro computers, ERP systems, E-mail usage, financial services, retail electronics, and personal computing (Gu, Lee \& Suh, 2009).

\section{Innovation diffusion theory}

Besides the TAM, the Innovations Diffusion Theory (IDT) proposed by Rogers (2003) could be considered as one of the most popular theories that have attempted to explore factors that affect an individual to adopt an innovation or a new technology. IDT is a theory that seeks to explain how, why, and at what rate new ideas and technology spread through cultures. Rogers defines diffusion as the adoption of an innovation "over time by the given social system", as a consequence diffusion processes result in the acceptance or penetration of a new idea, behavior, or physical innovation. According to $\mathrm{DT}$, the adoption rate of a new technology depends on five characteristics of the innovation, namely relative advantage, compatibility, complexity, observability, and trialability. Except for complexity, which has a negative relationship with the adoption rate, the other characteristics positively affect adoption intention of innovative technologies (Lin, 2011; Puschel, Mazzon \& Hernandez, 2010).

\section{Adoption and use of mobile banking}

There is numerous research conducted on mobile banking most recently. Early research on mobile banking was conducted primarily in the early $2000 \mathrm{~s}$. The mobile banking was researched from different perspective. Table 3 lists some of the research conducted on mobile banking most recently using different models of information technology.

\section{Research model and hypotheses}

This study uses TAM and IDT as theoretical models for explaining customer's intention to use mobile banking. With the advancement of technology and the use of innovative applications utilizing wired and wireless information and communication technology, additional factors need to be investigated to understand more fully the adoption of new applications, like mobile banking. This research has identified, based on previous studies (e.g. Gu et al., 2009; Lee, 2009; Lin, 2011; Zhou, 2011; Zhou, Lu \& Wang, 2010), several salient factors that are important drivers for mobile banking adoption. These factors are selfefficacy, compatibility, perceived risk and perceived trust. Perceived trust and risk are added as many users are inclined to use technologies that are compatible with their trustworthy, safe and secure and won't jeopardize their personal and financial information from being accessed by a third party.

\section{Perceived usefulness}

Perceived usefulness is defined in this study as the extent to which the customer believes that mobile banking is more advantageous when compared to other banking channels, like ATM or phone banking, for conducting banking services. These benefits include allowing them to accomplish banking activities more quickly, anytime, and anywhere. When customers perceive that the mobile banking services will be more useful, there is a greater chance that they are willing to use them. In other words, the main reason customers use mobile banking systems is that they find them useful and is "capable of being used advantageously" (Davis, 1989: 320).

$H_{1}$ : Perceived usefulness would positively affect intention to use mobile banking. 
Table 3: Summary of recent research studies on mobile banking

\begin{tabular}{|c|c|c|c|c|}
\hline SN & Author(s) & Country & Dependent Variable(s) & Independent Variables \\
\hline I & Lin (2011) & Taiwan & Attitude and behavioral intention & $\begin{array}{l}\text { perceived relative advantage, ease of use, } \\
\text { compatibility, perceived competence, } \\
\text { benevolence, and integrity }\end{array}$ \\
\hline 2 & Beiginia et al. (2011) & Iran & $\begin{array}{l}\text { Behavioral intention and actual } \\
\text { usage }\end{array}$ & $\begin{array}{l}\text { Subjective norm, perceived behavioral } \\
\text { control and attitude }\end{array}$ \\
\hline 3 & Zhou (2011) & China & $\begin{array}{l}\text { Trust, flow, usage intention, and } \\
\text { actual usage }\end{array}$ & $\begin{array}{l}\text { PEOU, Ubiquity, structural assurance, and } \\
\text { personal innovativeness }\end{array}$ \\
\hline 4 & $\begin{array}{l}\text { Riquelme \& Rios } \\
(2010)\end{array}$ & Singapore & Adoption intention & $\begin{array}{l}\text { PEOU, PU, relative advantage, risk, and } \\
\text { social norms }\end{array}$ \\
\hline 5 & Zhou et al. (2010) & China & Adoption and task-technology fit. & $\begin{array}{l}\text { Task, technology, performance expectancy, } \\
\text { effort expectancy, social influence, and } \\
\text { facilitating conditions }\end{array}$ \\
\hline 6 & Puschel et al. (2010) & Brazil & Adoption of mobile banking & $\begin{array}{l}\text { Perceived behavioral control, selective norm, } \\
\text { and attitude }\end{array}$ \\
\hline 7 & $\begin{array}{l}\text { Laukkanen \& Cruz } \\
(2008)\end{array}$ & $\begin{array}{l}\text { Finland and } \\
\text { Portugal }\end{array}$ & Resistance to adopt mobile banking & Value, risk, usage, tradition, and image \\
\hline 8 & Gu et al. (2009) & Korea & Behavioral intention & PEOU, PU, and trust \\
\hline 9 & Sulaiman et al, (2007) & Malaysia & Adoption & Demographics and personal Innovativeness \\
\hline 10 & Laforet \& Li (2005) & China & Actual Usage & Security and usefulness \\
\hline
\end{tabular}

\section{Perceived ease of use}

Perceived ease of use is defined as the degree to which mobile banking is perceived as easy to understand and operate (Lin, 2011). Puschel et al. (2010) found that perceived ease of use (PEOU) influences attitude towards mobile banking and this influences adoption and behavioral intentions towards mobile banking besides continuing to use the service. Lin (2011) tested the PEOU and its influence on adoption and asserted that PEOU in fact has a significant effect on adoption or continuing to use mobile banking. The TAM consistently has shown that PEOU is antecedent to perceived usefulness. This study hypothesizes that PEOU would have direct relationship with perceived usefulness as well as the intention to use mobile banking services.

\section{$H_{2}$ : PEOU would positively affect perceived usefulness of mobile banking.}

\section{$H_{3}$ : PEOU would positively affect intention to use mobile banking.}

\section{Perceived risk}

Perceived risk is defined as the probability or the possibility that the user might incur losses in the form of financial losses or personal account information by using mobile banking services. Laukanen and Cruz (2008) found that risk barriers are important in affecting mobile banking adoption. Riquelme and Rios (2010) identified that risk directly has impacted adoption of mobile banking. In this study, it is hypothesized that perceived risk would affect the intention to use mobile banking services.

$H_{4}$ : Perceived risk would negatively affect intention to use mobile banking.

\section{Compatibility}

Compatibility refers to the degree to which a service is perceived as consistent with users' existing values, beliefs, habits and present and previous experiences (Chen, Gillenson \& Sherrell, 2004). When mobile banking services become compatible with the user's needs and preferences, they would consider these services useful and carry out the transactions that fulfil their wants or needs. Puschel et al. (2010) found that compatibility affects attitude towards mobile banking which impacts adoption intention of mobile banking. This study hypothesizes that compatibility would have direct relationship with both PU and intention to use mobile banking services.

\section{$H_{5}$ : Compatibility would positively affect perceived usefulness of mobile banking.}

$H_{6}$ : Compatibility would positively affect intention to use mobile banking.

\section{Perceived trust}

Finally, trust is defined as the user's relative confidence in the mobile banking service itself. Having trust means that the user perceives the service as trustworthy. Mobile banking adoption by users has received attention by researchers. Eid (2011) found that perceived security risk and perceived privacy had negative relationship with trust of electronic commerce websites in Saudi Arabia. Chen and Chang (2012) found that perceived risk would negatively influence perceived trust and purchase intention. Zhou (2011) constructed a model to test the effect of trust on flow experience and the actual usage of mobile banking. Eriksson, Kerem and Nilsson (2005) have found trust has a positive effect on both perceived ease of use and perceived usefulness, In this study, it is hypothesized that perceived 
trust would negatively affect perceived risk and positively would affect perceived ease of use and perceived usefulness.

$H_{7}$ : Perceived trust would positively affect perceived usefulness of mobile banking.

$H_{8}$ : Perceived trust would positively affect PEOU of mobile banking.

$H_{9}$ : Perceived trust would negatively affect perceived risk of mobile banking.

\section{Self-efficacy}

Self-efficacy is defined as the level of confidence that a user possesses in using mobile banking technology and it considers the element of technology ease of use and having relative confidence in using the service. Gu et al. (2009) found that self-efficacy affects PEOU which influences behavioral intention towards mobile banking, however, the study concluded that the relationship was statistically insignificant. Puschel et al. (2010) found that self-efficacy had an impact on perceived behavioral control which influenced adoption intention or continuing to use mobile banking. This study hypothesizes that self-efficacy would have direct relationship with both PEOU.

$H_{10}$ : Self-efficacy would positively affect PEOU of mobile banking.

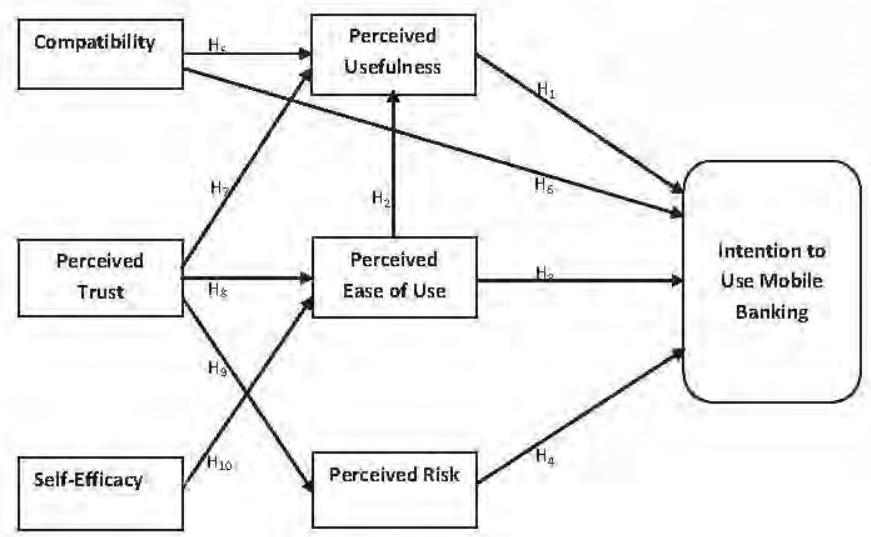

Figure 1: The research model
Based on the above discussions, Figure 1 illustrates the hypothesized relationships between the research model constructs.

\section{Research methodology}

\section{Measures}

Based on the review of prior research studies on internet and mobile banking (Gu et al., 2009; Lee, 2009; Lin, 2011; Zhou, 2011; Zhou et al., 2010), a draft survey instrument was developed for this study. The survey instrument consisted of three parts. The first part consisted of 25 items for 7 constructs. Some items were modified to suite the context of mobile banking. The measurement scale ranged from $1=$ strongly disagree to $7=$ strongly agree. The second part sought whether bank customers have used a number of mobile banking services that are offered through mobile devices by banks. The third part was designed to capture demographic characteristics of respondents like gender, age, education, income and occupation. Table 4 shows each construct and its associated items as well as the sources of these items.

\section{Data collection}

The data for this research study was collected using survey questionnaires distributed to bank customers residing in the eastern province of Saudi Arabia. The data collected during March and April, 2011. Some questionnaires were distributed manually and others online, generating 253 usable responses. The profile of the respondents was summarized in Table 5. The demographic characteristics indicated that the majority of respondents were male ( $91 \%$ ), married $(83 \%)$, between 30 and 49 years old $(75 \%)$, Saudi nationals $(82 \%)$, have bachelor degree $(58 \%)$, earn between 10,000 and 20,000 Saudi Riyals (46\%), and government employee $(75 \%)$. The majority of sample respondents have not used mobile banking services at all $(67 \%)$. 
Table 4: Constructs and their items

\begin{tabular}{|c|c|c|}
\hline Construct & Item & Reference \\
\hline Perceived & PU1: I think using M-banking would enable me to accomplish my tasks more quickly & \\
\hline \multirow[t]{3}{*}{ Usefulness } & PU2: I think using M-banking would make it easier for me to carry out my tasks & \\
\hline & PU3: I think M-banking is useful & Lee (2009) \\
\hline & PU4: Overall, I think using the M-banking is advantageous & \\
\hline \multirow{3}{*}{$\begin{array}{l}\text { Perceived Ease of } \\
\text { Use }\end{array}$} & PE1: I think learning to use M-banking would be easy & \\
\hline & PE2: I think the interaction with M-banking does not require a lot of mental effort & \\
\hline & PE3: I think it is easy to use M-banking to accomplish my banking tasks & Lee (2009) \\
\hline \multirow[t]{4}{*}{ Perceived Trust } & PT1: M-banking is trustworthy & Gu et al. (2009) \\
\hline & PT2: M-banking keeps its promise & Zhou (2011) \\
\hline & PT3: M-banking keeps customers' interests in mind & \\
\hline & PT4: Overall, I trust M-banking & \\
\hline \multirow[t]{5}{*}{ Perceived Risk } & PR1: I would not feel safe providing personal privacy information over the M-banking & \\
\hline & PR2: I'm worried to use M-banking because other people may be able to access my account & \\
\hline & PR3: I would not feel secure sending sensitive information across the M-banking & \\
\hline & PR4: When transferring money using M-banking, I am afraid that I will lose my money & \\
\hline & PR5: Using M-banking in monetary transactions has potential risk & Lee $(2009)$ \\
\hline \multirow[t]{2}{*}{ Self-Efficacy } & SE1: I do not feel difficulties to use M-banking & Gu et al. $(2009)$ \\
\hline & $\begin{array}{l}\text { SE2: I do not need some people's help to use M-banking } \\
\text { SE3: I have a confidence to use M-banking }\end{array}$ & \\
\hline \multirow[t]{3}{*}{ Compatibility } & CM1: Using M-banking is compatible with most aspects of my online transactions & $\operatorname{Lin}(2011)$ \\
\hline & CM2: Using M-banking fits my lifestyle & \\
\hline & CM3: Using M-banking fits well with the way I like to engage in online transactions & \\
\hline \multirow[t]{3}{*}{ Intention to Use } & IU1: I would use M-banking for my banking needs & Lee (2009) \\
\hline & IU2: Using M-banking for handling my banking transactions is something I would do & \\
\hline & IU3: I would see myself using M-banking for handling my banking transactions & \\
\hline
\end{tabular}

Table 6 summarized the use of mobile banking services by bank customers. Nine to eleven percent indicated that their banks have not offered mobile banking services. The majority have not used mobile banking services. All these mobile services are offered via different channels like ATM,

Table 5: Demographic characteristics of the respondents internet, and face-to-face. Of those who have used mobile banking services, they mostly view mini-statement and check account information, pay government bills and transfer funds between accounts.

\begin{tabular}{|c|c|c|c|}
\hline Variable & & $\mathrm{N}$ & $\%$ \\
\hline \multirow[t]{2}{*}{ Gender } & Male & 231 & 91,3 \\
\hline & Female & 22 & 8,7 \\
\hline \multirow[t]{2}{*}{ Marital Status } & Single & 43 & 17,0 \\
\hline & Married & 210 & 83,0 \\
\hline \multirow[t]{4}{*}{ Age (years) } & $20-29$ & 39 & 15,4 \\
\hline & $30-39$ & 100 & 39,5 \\
\hline & $40-49$ & 89 & 35,2 \\
\hline & 50 or above & 25 & 9,9 \\
\hline \multirow[t]{2}{*}{ Nationality } & Saudi & 207 & 81,8 \\
\hline & Non-Saudi & 46 & 18,2 \\
\hline \multirow[t]{3}{*}{ Education } & Diploma & 16 & 6,3 \\
\hline & Bachelor & 146 & 57,7 \\
\hline & Master/Doctorate & 91 & 36,0 \\
\hline \multirow[t]{4}{*}{ Monthly Income (SAR*) } & Below 10,000 & 31 & 12,3 \\
\hline & $10,000-19,999$ & 117 & 46,2 \\
\hline & $20,000-29,999$ & 87 & 34,4 \\
\hline & Over 30,000 & 18 & 7,1 \\
\hline \multirow[t]{4}{*}{ Occupation } & Government Employee & 190 & 75,1 \\
\hline & Private Employee & 58 & 22,9 \\
\hline & Self-Employed & 3 & 1,2 \\
\hline & Student & 2 & 0,8 \\
\hline \multirow[t]{5}{*}{ Mobile Banking Experience } & Not used at all & 169 & 66,8 \\
\hline & Less than 6 months & 18 & 7,1 \\
\hline & 6 months to 1 years & 34 & 13,4 \\
\hline & 1 to 3 years & 28 & 11,1 \\
\hline & More than 3 years & 4 & 1,6 \\
\hline
\end{tabular}


Table 6: Use of mobile banking services

\begin{tabular}{|c|c|c|c|c|}
\hline SN & M-Banking Services & Don't Use & Use & Not Offered \\
\hline 1 & Transfer fund between accounts within same bank & 60,1 & 31,2 & 8,7 \\
\hline 2 & Transfer fund between local banks & 68,8 & 22,1 & 9,1 \\
\hline 3 & Transfer fund to banks outside Saudi Arabia & 79,8 & 11,1 & 9,1 \\
\hline 4 & Pay credit cards & 64,8 & 26,5 & 8,7 \\
\hline 5 & Pay loan instalments & 81,0 & 7,9 & 11,1 \\
\hline 6 & Pay government bills & 59,3 & 32,0 & 8,7 \\
\hline 7 & View a mini-statement \& check account information & 58,1 & 33,2 & 8,7 \\
\hline 8 & IPO (Stock Market) Subscription & 81,4 & 9,5 & 9,1 \\
\hline
\end{tabular}

\section{Results}

The research model was tested using the Partial Least Square (PLS) method and used the software application SmartPLS 2.0. (Ringle, Wende \& Will, 2005). PLS was chosen primarily because it is able to model latent constructs under nonnormality and small to medium sample sizes. The evaluation of the research model according to PLS follows a two-stage process (Chin, 2010). The first stage is the evaluation of the measurement model by investigating the reliability and the convergent and discriminant validity of the constructs. The second stage is evaluating the structural model by testing the significance of the relationships between the model constructs.

\section{The measurement model}

Table 7 presents the mean, standard deviation (SD), Cronbach Alpha (CA), composite reliability (CR), and

Table 7: Mean, standard deviation, and reliability scores average variance extracted (AVE) for all model constructs. All CA and CR scores exceeded the recommended value of 0,70 (Nunnally \& Bernstein, 1994), indicating that all constructs possessed good reliability.

Convergent validity involves the degree to which individual items reflecting a construct converge in comparison to items measuring different constructs. A commonly applied criterion of convergent validity is the AVE proposed by Fornell and Larcker (1981). An AVE value of 0,500 or more indicates that a construct explains more than half of the variance of its indicators and, thus, demonstrates sufficient convergent validity. All AVEs, presented in Table 7, ranged from 0,687 to 0,930 , much higher than the cut-off value of 0,500 . In addition, all the factor loadings and their corresponding $t$-values, presented in Table 8 , exceeded 0,7 and $1,96(\mathrm{P}<0,05)$, respectively, thereby demonstrating adequate convergent validity

\begin{tabular}{|c|c|c|c|c|c|}
\hline Construct & Mean & SD & $\mathrm{CA}$ & $\mathrm{CR}$ & $\mathrm{AVE}$ \\
\hline Usefulness & 6,287 & 0,670 & 0,866 & 0,909 & 0,713 \\
\hline Ease of Use & 6,240 & 0,743 & 0,841 & 0,904 & 0,759 \\
\hline Trust & 5,874 & 0,836 & 0,851 & 0,898 & 0,687 \\
\hline Risk & 3,443 & 1,309 & 0,937 & 0,952 & 0,802 \\
\hline Self-Efficacy & 5,827 & 0,747 & 0,973 & 0,878 & 0,707 \\
\hline Compatibility & 5,681 & 0,921 & 0,859 & 0,913 & 0,778 \\
\hline Intention to Use & 5,643 & 1,211 & 0,963 & 0,976 & 0,930 \\
\hline
\end{tabular}

To assess the discriminant validity, Fornell and Larcker (1981) suggest the use of AVE, the average variance shared between a construct and its measures. The AVE should be greater than the variance shared between the construct and other constructs in the model (i.e., the squared correlation between two constructs). The diagonal elements of Table 9 are the square roots of AVEs of the construct, while offdiagonal entries are the inter-construct correlation coefficients. For adequate discriminant validity, the diagonal elements should be greater than the off-diagonal elements in the corresponding rows and columns. All square roots of AVEs in Table 9 were greater than the corresponding interconstruct correlation, therefore confirming discriminant validity. 
Table 8: Confirmatory factor analysis

\begin{tabular}{lllll}
\hline Construct & Item & Loadings & Standard Error & t-value \\
\hline Perceived Usefulness (PU) & PU1 & 0,874 & 0,027 & 31,898 \\
& PU2 & 0,835 & 0,030 & 28,321 \\
& PU3 & 0,834 & 0,045 & 18,666 \\
& PU4 & 0,834 & 0,047 & 17,681 \\
\hline Perceived Ease of Use (PE) & PE1 & 0,884 & 0,028 & 31,962 \\
& PE2 & 0,837 & 0,042 & 20,097 \\
\hline Perceived Trust (PT) & PE3 & 0,892 & 0,025 & 36,260 \\
& PT1 & 0,844 & 0,024 & 35,514 \\
& PT2 & 0,879 & 0,016 & 53,554 \\
& PT3 & 0,814 & 0,038 & 21,198 \\
& PT4 & 0,786 & 0,055 & 14,353 \\
\hline Perceived Risk (PR) & PR1 & 0,928 & 0,016 & 58,941 \\
& PR2 & 0,949 & 0,011 & 87,643 \\
& PR3 & 0,955 & 0,010 & 90,579 \\
& PR4 & 0,935 & 0,014 & 66,212 \\
& PR5 & 0,679 & 0,054 & 12,592 \\
\hline Self-Efficacy (SE) & SE1 & 0,870 & 0,025 & 34,489 \\
& SE2 & 0,862 & 0,033 & 25,856 \\
\hline SE3 & 0,788 & 0,058 & 13,621 \\
\hline Intention to Use (IU) & CM1 & 0,867 & 0,024 & 35,625 \\
& CM2 & 0,869 & 0,022 & 38,954 \\
& CM3 & 0,910 & 0,010 & 89,528 \\
\hline
\end{tabular}

Table 9: Construct correlation coefficients and square root of AVEs*

\begin{tabular}{lrrrrrrr}
\hline & \multicolumn{1}{c}{ PU } & PE & \multicolumn{1}{c}{ PT } & PR & SE & CM & IU \\
\hline PU & $\mathbf{0 , 8 4 5}$ & & & & & & \\
PE & 0,623 & $\mathbf{0 , 8 7 1}$ & & & & & \\
PT & 0,533 & 0,570 & $\mathbf{0 , 8 2 9}$ & & & & \\
PR & $-0,098$ & 0,001 & $-0,250$ & $\mathbf{0 , 8 9 5}$ & & & \\
SE & 0,392 & 0,385 & 0,432 & $-0,163$ & $\mathbf{0 , 8 4 1}$ & & \\
CM & 0,386 & 0,374 & 0,489 & $-0,361$ & 0,625 & $\mathbf{0 , 8 8 2}$ & \\
IU & 0,340 & 0,297 & 0,433 & $-0,411$ & 0,450 & 0,806 & $\mathbf{0 , 9 6 5}$ \\
\hline
\end{tabular}

\section{The structural model}

The proposed research model explained $66,7 \%$ of the variance in intention to use mobile banking, providing good explanatory power. The Stone-Geisser's $Q^{2}$ (Stone, 1974; Geisser, 1975) is used as a criterion for predictive relevance of the structural model. Using blindfolding procedure (Tenenhaus, EspositoVinzi, Chatelin \& Lauro, 2005), the cross-validated redundancy $\mathrm{Q}^{2}$ for intention to use was 0,616 . Value of $Q^{2}$ greater than zero is indicative of predictive relevance of the structural model (Henseler, Ringle \& Sinkovics, 2009). The path coefficients are shown in Figure 2. There were direct effects of perceived risk and compatibility on intention to use mobile banking, supporting $\mathrm{H}_{4}$ and $\mathrm{H}_{6}$, respectively. However, perceived ease of use and perceived usefulness had no direct significant effects on intention to use mobile banking, not supporting $\mathrm{H}_{1}$ and $\mathrm{H}_{3}$. Perceived ease of use, compatibility, and perceived trust had a significant effect on perceived usefulness of mobile banking, supporting $\mathrm{H}_{2}, \mathrm{H}_{5}$ and $\mathrm{H}_{7}$. Self-efficacy had no significant effect on PEOU, not supporting $\mathrm{H}_{10}$, while trust had significant effect of PEOU, supporting $\mathrm{H}_{8}$. Perceived trust had significant negative effect on perceived risk, supporting $\mathrm{H}_{9}$. Table 10 summarized the hypotheses testing results.

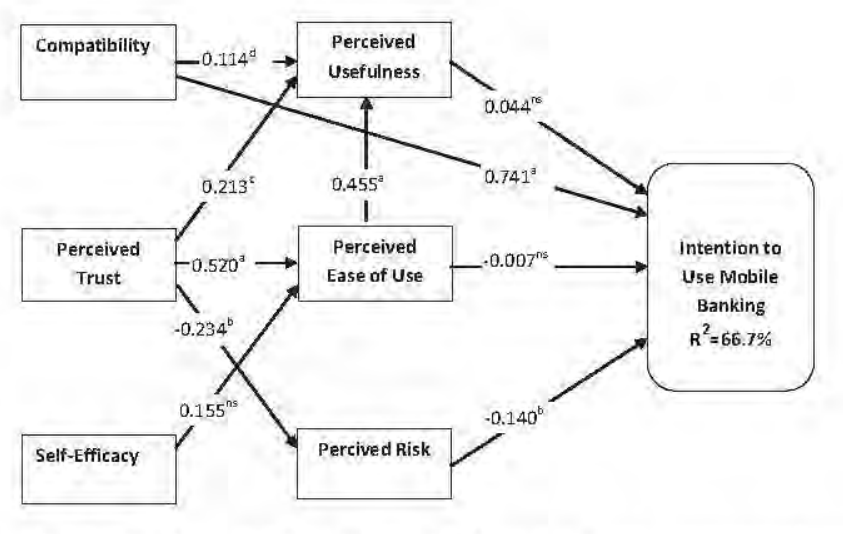

${ }^{\mathrm{a}} P<0,000,{ }^{\mathrm{b}} P<0,005,{ }^{\circ} P<0,050,{ }^{\mathrm{d}} P<0,100, \mathrm{~ns}=$ not significant

Figure 2: Research model with path coefficients and $\mathrm{R}^{2}$ of endogenous variables 
Table 10: Results of hypotheses testing

\begin{tabular}{|c|c|c|c|c|}
\hline Hypothesis & Path & Coefficient & T-Value & Support \\
\hline $\mathrm{H}_{1}$ & Perceived usefulness -.-> Intention to use & 0,044 & $0,875^{\mathrm{ns}}$ & No \\
\hline $\mathrm{H}_{2}$ & PEOU ‥>> Perceived usefulness & 0,455 & $4,405^{\mathrm{a}}$ & Yes \\
\hline $\mathrm{H}_{3}$ & PEOU $\ldots$ Intention to use & $-0,007$ & $0,146^{\mathrm{ns}}$ & No \\
\hline $\mathrm{H}_{4}$ & Perceived risk ---> Intention to use & $-0,140$ & $3,008^{b}$ & Yes \\
\hline $\mathrm{H}_{5}$ & Compatibility $--->$ Perceived usefulness & 0,114 & $1,830^{\mathrm{d}}$ & Yes \\
\hline $\mathrm{H}_{6}$ & Compatibility $-->$ Intention to use & 0,741 & $17,171^{\mathrm{a}}$ & Yes \\
\hline $\mathrm{H}_{7}$ & Perceived trust $-->>$ Perceived usefulness & 0,213 & $2,344^{\mathrm{c}}$ & Yes \\
\hline $\mathrm{H}_{8}$ & Perceived trust $-->$ PEOU & 0,520 & $6,480^{a}$ & Yes \\
\hline $\mathrm{H}_{9}$ & Perceived trust $\rightarrow->$ Perceived risk & $-0,234$ & $2,997^{b}$ & Yes \\
\hline $\mathrm{H}_{10}$ & Self-efficacy $\ldots$ PEOU & 0,155 & $1,608^{\text {ns }}$ & No \\
\hline
\end{tabular}

${ }^{\mathrm{a}} P<0.000,{ }^{\mathrm{b}} P<0.005,{ }^{\mathrm{c}} P<0.050,{ }^{\mathrm{d}} P<0.100$, ns $=$ not significant

\section{Discussion}

About $67 \%$ of the respondents have not used mobile banking at all. Many customers, during interviews, expressed their preference to other banking channels; others feel no urgency of adopting the service, use alternative electronic channels of banking, and some unaware of the mobile banking services, or the services were not offered by their primary bank. Almost all of the services that are provided through mobile phones are also available in other channels, like ATM, phone, internet and even face-to-face banking. The difference is that, in mobile banking, customers can use the banking services at their convenience, anytime, and anywhere.

Seven of ten hypotheses were significantly supported. The remaining three hypotheses were not supported in this study. The factors that directly affect mobile banking adoption were compatibility and risk. Compatibility had the strongest positive effect on the intention to use. This implies that mobile banking services fit well with customers working environment and lifestyles, and therefore, they like adopting such innovation. When customers or prospective customers perceive that using mobile banking is completely compatible with their current ways of banking and it fits well with the way they like to do banking, they tend to adopt it.

Risk had negative effect on intention to use. Risk may emanate from different sources, including loss of the phone device, internet security breaches, identity theft, invasion of private information, and/or lack of trust in the bank technology infrastructure. This is in line with most of the previous research findings (Chen, 2008; Tan \& Teo, 2000), which means that bank customers perceive risk as a major hindrance to the adoption of mobile banking. Customers fear that they may lose their money and don't feel safe sending sensitive information across the wireless network. In mobile banking, financial transactions are conducted over mobile network or through a wireless internet connection as opposed to internet banking which also might be conducted over a wireless internet connection or through phone lines. Some would argue that conducting banking transactions over wireless mobile network is risky as opposed to using the conventional wired-network. This implies that bank management should address customers' concern and provide assurances that their banking transactions are safe; and the mobile banking system is safe and trustworthy.
Perceived trust had significant effect on perceived usefulness, PEOU, and perceived risk. However, perceived trust had negative significant effect on perceived risk, and perceived risk had significant negative effect on intention to use mobile banking, suggesting that perceived trust affect intention to use indirectly through perceived risk. This implies that customers who demonstrate trust in the mobile banking services would perceive less risk toward using mobile banking services. Normally, people will resist using mobile banking if it is prone to potential risk. Trust in bank, wireless channel, and mobile device will compensate for probable risk concerns that may arise when using mobile banking services. When banks put customer's interest in mind, they will perceive mobile banking to be less risky and they intend to use mobile banking services. On the contrary, customers will resist using mobile services if they don't trust them. Trust may emanate from previous experience in interacting with the bank or assurances such as guarantees against security breaches or invasion of privacy.

Trust had strong significant effect on PEOU and perceived usefulness. Higher levels of trust allow customers to take advantage of mobile banking services. Customers would tend to use and realize the expected benefits from using mobile banking services. Trusting that financial transactions will be secure may also make mobile banking more useful. The positive relationship between perceived trust and PEOU is in congruence with the findings of Chircu, Davis \& Kauffman (2000). The more a customer trusted that their financial transactions would be safe, the higher their belief that mobile banking was easy to use and useful. The logic behind this is that trust reduces the learning and mental effort in understanding, monitoring, and checking every detail related to financial transactions.

Contrary to previous research, neither PEOU nor perceived usefulness affected the intention to use. One possible explanation is that most of the sample respondents $(67 \%)$ never used mobile banking at all, because either they use other alternative channels or are not able to express their perceptions accurately toward mobile banking experience. Thus, they had difficulty evaluating the ease of use and usefulness of mobile banking. Or they may perceived mobile banking as easy and useful as any other channels, like ATM, telephone, or even internet banking. 


\section{Conclusion and implications}

This research paper provides an insight on the factors influencing intention to use mobile banking in Saudi Arabia. At the time of the study, only 5 of 12 banks operating in Saudi Arabia offer mobile banking services. Many bank customers have not yet used mobile banking. Compatibility and perceived risk had significant impact on the intention to use mobile banking whereas trust had an indirect impact via perceived risk. Perceived usefulness and PEOU had no significant effect on customer's intention to use mobile banking.

This study has implications for research and practice. On the practical side, the results have shown compatibility is powerful driver to the intention to use mobile banking and perceived risk is severe hindrance. Bank customers are sensitive to risk. Therefore, banks should seek ways and means to build trust in order to alleviate this risk. When customers trust the bank, they would continue conducting financial transactions over the mobile banking channel even it is risky because that have confidence in banks to act in their favour. Mobile banking is expected to attract new technologically savry customers which would increase the customers' base, and eventually increase revenues and profitability. Although ATM's, phone and internet banking are the most popular channels for conducting personal financial transactions nowadays, it is expected that mobile banking becomes the potential channel for future banking services. However, banks need to offer more mobile banking services and increase awareness of their customers. This can be done by advertising in their websites, newspapers, social media, TVs, or through SMS messages; which can be an effective way of spreading the use of mobile banking services. So, increased marketing efforts, especially through advertising, would help banks to increase customer awareness and attract more customers who would use mobile banking services.

\section{Limitation and future research}

This research has few limitations. First, the research has used convenience-sampling techniques in data collection because of the difficulty in using random sampling in Saudi Arabia. This limits the generalizability of the results. Second, the use of mobile banking is still in its infancy stage. Few banks offer mobile banking with few and limited number of services. Therefore, this study may need to be replicated when the usage becomes more mature.

Researchers need to explore other factors that are suitable for the mobile banking context, like ubiquity, convenience, and security, social influence and personal innovativeness that may affect the intention to use mobile banking. The research model of this study provided basis for further investigations and refinement of technology adoption models (TAM). While TAM is useful for traditional application adoption, it is not sufficient in explaining other important factor in determining web-based mobile application adoption. This study is a cross-sectional study.
Since user behavior is dynamic, a longitudinal study may provide more insights on user behavior dynamics and development.

\section{Acknowledgement}

The author would like to thank King Fahd University of Petroleum \& Minerals, for the administrative and financial support provided for this research. Special thanks to Mr. M. Fallatah for his help in the data collection stage.

\section{References}

Ajzen, I. \& Fishbein, M. 1980. Understanding attitudes and predicting social behavior, Englewood Cliffs, New Jersy: Prentice-Hall.

Al-Ashban, A.A. \& Burney, M.A. 2001, 'Customer adoption of tele-banking technology: The case of Saudi Arabia', International Journal of Bank Marketing, 19(5): 191-200.

Al-Jabri, I.M. \& Sohail, M.S. 2012. 'Mobile banking adoption: Application of diffusion of innovation theory', Journal of Electronic Commerce Research, 13(4): 379-391.

Al-Somali, S.A., Gholami, R. \& Clegg, B. 2009. 'An investigation into the acceptance of online banking in Saudi Arabia', Technovation, 29(2): 130-141.

Bhattacherjee, A. 2002. 'Individual trust in online firms: scale development and initial test: Scale development and initial test', Journal of Management Information Systems, 19(1): 211-241.

Beiginia, A.R., Besheli, A.S., Soluklu, M.E. \& Ahmadi, M. 2011. 'Assessing the mobile nanking adoption based on the decomposed theory of planned behaviour', European Joumal of Economics, Finance and Administrative Sciences, 28: 7-15.

Chen, L. 2008. 'A model of consumer acceptance of mobile payment', International Journal of Mobile Communications, 6(1): $32-52$.

Chen, Y.-S. \& Chang, C.-H. 2012. 'Enhance green purchase intentions: The roles of green perceived value, green perceived risk, and green trust', Management Decision, 50(3): $502-520$

Chen, L., Gillenson, M. \& Sherrell, D. 2004. 'Consumer acceptance of virtual stores: A theoretical model and critical success factors for virtual stores', ACM SIGMIS Database, $35(2): 8-31$.

Chin, W. (2010). How to Write Up and Report PLS Analyses. In Esposito Vinzi, V., Chin, W., Henseler, J. \& Wang, H. (Eds.). Handbook of Partial Least Squares: Concepts, Methods and Applications, (pp. 655-690), Berlin: Springer. 
Chircu, A.M., Davis, G.B. \& Kauffman, R.J. 2000. 'Trust, expertise and ecommerce intermediary adoption'. In Proceedings of the Sixth Americas Conference on Information Systems, Long Beach, CA, August 3-5.

CITC 2012. '53.1 million mobile subscriptions at the end of Q3 2012 in KSA', CITC Newspaper No. 013. [online] URL: http:/Www.citc.gov.sa/English/MediaCenter/CITCinthemed ia/Pages/PR_MED_129.aspx

Davis, F.D. 1986. "A technology acceptance model for empirically testing new end-user information systems: Theory and results, 'doctoral dissertation, MIT Sloan School of Management, Cambridge, MA.

Davis, F.D. 1989. 'Perceived usefulness, perceived ease of use, and user acceptance of information technology', MIS Quarterly, 13(3): 319-340.

Davis, F. D., Bagozzi, R.P. \& Warshaw, P.R. 1989. 'User acceptance of computer technology: A comparison of two theoretical models', Management Science, 35(8): 982-1003.

Eid, M.I. 2011. 'Determinants of e-commerce customer satisfaction, trust, and loyalty in Saudi Arabia', Joumal of Electronic Commerce Research, 12(1): 78-93.

Eriksson, K., Kerem, K. \& Nilsson, D. 2005. 'Customer acceptance of internet banking in Estonia", International Journal of Bank Marketing, 23(2): 200-216.

Ethos Interactive 2012. 'Saudi Digital Mobile Stats - 2012 - By Google'. [online] URL: http://blog.ethosinteract.com/ 2012/05/28/saudi-digital-mobile-stats-2012-by-google

Fishbein, M. \& Ajzen, I. 1975. Belief attitude, intention and behaviour: An intraduction to theory and research, MA, Addison-Wesly.

Fornell, C. \& Larcker, D.F. 1981. 'Evaluating structural equation models with unobservable variables and measurement error', Journal of Marketing Research, 18(1): 39-50.

Gefen, D., Karahanna, E. \& Straub, D.W. 2003. 'Trust and TAM in online shopping: An integrated model', MIS Quarterly, 27(1): 51-90.

Geisser, S. 1975. "A predictive approach to the random effect model ${ }^{\text {, }}$, Biometrika, 61(1): 101-107.

Gu, J.-C., Lee, S.-C. \& Suh, Y.-H. 2009. 'Determinants of behavioral intention to mobile banking', Expert Systems with Applications, 36(9): 11605-11616.

Henseler, J., Ringle, C. M., \& Sinkovics, R. R. 2009. The use of partial least squares path modeling in international marketing. In Sinkovics, R. R. \& Ghauri, P. N. (Eds). Advances in International Marketing, 20, Emerald.
Kim, G., Shin, B. \& Lee, H.G. 2009. "Understanding dynamics between initial trust and usage intentions of mobile banking', Information Systems Journal, 19(3); 283311.

Laforet, S. \& Li, X. 2005. 'Consumers' attitudes towards online and mobile banking in China', International Journal of Bank Marketing, 23(5): 362-380.

Laukkanen, T. \& Cruz, P. 2008. Comparing consumer resistance to mobile banking in Finland and Portugal. In Filipe, J. \& Obaidat, M.S. (Eds) ICETE 2008, CCIS 48, Berlin Heidelberg: Springer-Verlag.

Lee, K.S., Lee, H.S. \& Kim, S.Y. 2007. 'Factors influencing the adoption behavior of mobile banking: A South Korean perspective', Journal of Internet Banking and Commerce, 12(2), [online] URL: http://www.arraydev.com/commerce/ jibc/2007-08/HyungSeokLee_Final_PDF\%20Ready.pdf

Lee, M.-C. 2009. 'Factors influencing the adoption of internet banking: An integration of TAM and TPB with perceived risk and perceived benefit', Electronic Commerce Research and Applications, 8(3): 130-141.

Lin, H.-F. 2011. "An empirical investigation of mobile banking adoption: The effect of innovation attributes and knowledge-based trust, International Journal of Information Management, 31(3): 252-260.

Lin, F., Fofanah, S.S. \& Liang, D. 2011. 'Assessing citizen adoption of e-Government initiatives in Gambia: A validation of the technology acceptance model in information systems success; , Government Information Quarterly, 28(2): 271-279.

Mahdi, M.O.S. 2012. 'Gender views on trust in e-banking services in Saudi Banks", World Review of Business Research, 2(1): 36-49.

Monthly Statistical Bulletin 1/2012. Monthly Statistical Bulletin. [online] URL: http://www.sama.gov.sa/sites/ samaen/ReportsStatistics/statistics/Pages/MonthlyStatistics.a spx

Nunnally, J.C. \& Bernstein, I.H. 1994. Psychometric Theory. New York, McGraw-Hill.

Park, N., Roman, R., Lee, S. \& Chung, J.E. 2009. 'User acceptance of a digital library system in developing countries: An application of the technology acceptance model', International Journal of Information Management, 29(3): 196-209.

Pavlou, P.A. 2003. 'Consumer acceptance of electronic commerce: Integrating trust and risk with the technology acceptance model', International Journal of Electronic Commerce, 7(3): 101-134. 
Puschel, J., Mazzon, A. \& Hernandez, J.M.C. 2010. 'Mobile banking: Proposition of an integrated adoption intention framework', International Journal of Bank Marketing, 28(5): 389-409.

Riffai, M.M.M.A., Grant, K. \& Edgarc, D, 2012. 'Big TAM in Oman: Exploring the promise of on-line banking, its adoption by customers and the challenges of banking in Oman', International Journal of Information Management, 32(2); 239-250.

Ringle, C., Wende, S. \& Will, A. 2005. Smart PLS 2.0 (beta), University of Hamburg. [online] URL: http://Www.smartpls.de

Riquelme, H.E. \& Rios, R.E. 2010. 'The moderating effect of gender in the adoption of mobile banking', International Journal of Bank Marketing, 28(5): 328-341.

Rogers, E. 2003. Diffusion of innovations, New York: Free Press.

Stone, M. 1974, "Cross-validatory choice and assessment of statistical predictions', Journal of the Royal Statistical Society, 36(2); 111-147.

Suh, B. \& Han, I. 2002. "Effect of trust on customer acceptance of internet banking', Electronic Commerce Research and Applications, 1(3-4): 247-263.

Sundarraj, R.P. \& Manochehri, N. 2011. 'Application of an extended TAM model for online banking adoption: A study at a gulf-region university', Information Resources Management Journal, 24(1): 1-13.

Sulaiman, A., Jaafar, N.I. \& Mohezar, S. 2007. "An overview of mobile banking adoption among the urban community, International Journat of Mobile Communications, 5(2): 157-168.

Tan, M. \& Teo, T.S.H. 2000. 'Factors influencing the adoption of internet banking', Journal of the Association for Information Systems, 1(5): 1-44.

Tenenhaus, M., EspositoVinzi,V., Chatelin,Y.-M. \& Lauro, C. 2005. 'PLS path modeling', Computational Statistics \& Data Analysis, 48(1): 159-205.

Zhao, A.L. \& Koenig-Lewis, N. 2010. 'Adoption of internet banking services in China: Is it all about trust?', International Journal of Bank Marketing, 28(1): 7-26.

Zhou, T. 2012. 'Understanding users' initial trust in mobile banking: An elaboration likelihood perspective', Computers in Human Behavior, 28(4): 1518-1525.

Zhou, T. 2011. 'Examining mobile banking user adoption from the perspectives of trust and flow experience'. Information Technology and Management, 13(1):27-37.
Zhou, T., Lu, Y. \& Wang, B. 2010. "Integrating TTF and UTAUT to explain mobile banking user adoption", Computers in Human Behavior, 26(4): 760-767. 